\title{
Tingkat pengetahuan tentang pemantauan gerakan janin pada ibu hamil dengan preeklampsia
}

\author{
Fitri Yani*, Dian Roza Adila, Riau Roslita \\ Program Studi Keperawatan STIKes Hangtuah Pekanbaru \\ yaniipit1202@gmail.com \\ *Correspondent Author
}

Article history

Received 26 September 2020

Revised 16 Februari 2021

Accepted 23 Februari 2021

Keywords

Knowledge level

Fetal movement

Pregnant

Preeclampsia
Preeclampsia is a pregnancy complication that can cause fetal and maternal morbidity and mortality. One way that pregnant women can reduce the risk of pregnancy complications is by monitoring the fetus's movement. The mother must know about monitoring fetal movements by analyzing fetal movements. The mother can detect the health of the fetus from an early stage. This study aims to determine the level of knowledge about monitoring fetal movement in pregnant women with preeclampsia. This quantitative research uses a simple descriptive design. The study's location is in the inpatient room of Teratai 1 and the Arifin Ahmad Hospital's obstetrics department, Riau Province. The population is 85 people. The selected sample amounted to 46 people with accidental techniques. The data was collected using a questionnaire and then analyzed univariately. The study found that $80.4 \%$ of pregnant women lacked knowledge about monitoring fetal movements. Pregnant with preeclampsia need to pay more attention to their fetal movements by seeking more information from health services and other sources, such as social media. Lack of monitoring of fetal movements and maternal knowledge about it causes fetal and maternal mortality rates to be challenging to reduce. Therefore, health workers must be more active in educating about pregnant women's health problems with preeclampsia to achieve the SDGs target in reducing infant and maternal mortality.

This is an open-access article under the CC-BY-SA license.

\section{Pendahuluan}

Masa kehamilan dan persalinan merupakan masa yang paling rentan bagi perempuan dan anak. Menurut perkiraan UNICEF, terdapat 2,8 juta kematian ibu hamil dan bayi baru lahir setiap tahun atau 1 kematian setiap 11 detik. Sebagian besar kematian ibu dan bayi disebabkan oleh halhal yang bisa dicegah (1). Oleh karena tingginya angka kematian ibu dan bayi, maka forum Sustainable Development Goals (SDGs) menargetkan untuk menurunkan Angka Kematian Bayi menjadi kurang 12 per 1.000 kelahiran hidup dan target penurunan rasio kematian ibu menjadi kurang dari 70 per 100.000 kelahiran pada tahun 2030. Di Indonesia Angka Kematian Bayi telah mengalami penurunan sejak beberapa decade terakhir, akan tetapi angkanya masih tinggi yakni 32 anak per 1000 kelahiran hidup. Rencana Pembangunan Jangka Menengah (RPJM) 2015-2019 menargetkan penurunan Angka Kematian Bayi 24 per 1.000 kelahiran hidup pada tahun 2019. Angka kematian Ibu di Indonesia 305 per 100.000 kelahiran, penurunan angka kematian ibu diharapkan menjadi 183 per 100.000 kelahiran pada tahun 2024 (1). Jumlah kematian ibu di Propinsi Riau pada tahun 2014 sebanyak 153 kasus kematian ibu dan pada tahun 2015 sedikit 
menurun menjadi 145 kasus dan menurun kembali di tahun 2016 menjadi 130 kasus kematian ibu, tahun 2017 jumlah kematian ibu sebesar 295. Penyebab kematian ibu diantaranya karena perdarahan postpartum, post SC, preeklampsia dan lain-lain (2).

Angka Kematian Bayi berkaitan erat dengan kualitas pelayanan persalinan dan penanganan yang kurang optimal setelah lahir dan beberapa hari pertama setelah lahir, sedangkan penyebab kematian utama pada ibu hamil adalah komplikasi kehamilan. Kejadian komplikasi berkisar $7-$ $10 \%$ dari seluruh kehamilan(3). Sekitar 10-15\% angka kematian ibu hamil terjadi karena preeklampsia. Sehingga preeklampsia selalu dikaitkan dengan penyakit maupun kematian dari ibu dan janin dan menjadi penyebab kedua terbesar kematian ibu dan bayi (4). Preeklampsia merupakan komplikasi pada kehamilan usia 20 minggu yang ditandai dengan tingginya tekanan darah, meski ibu tidak memiliki riwayat hipertensi. Kondisi preeklampsia merupakan masalah kesehatan yang berbahaya bagi ibu dan berdampak pada keselamatan janin dalam kandungan (5).

Penyebab komplikasi preeklampsia adalah adanya gangguan terhadap pertumbuhan dan perkembangan plasenta sehingga menyebabkan sirkulasi darah yang menghubungkan ibu dan janin terganggu. Ketika plasenta yang berfungsi sebagai penyalur oksigen dan nutrisi tidak berjalan sebagaimana mestinya, maka tubuh janin yang ada dalam kandungan tidak mendapatkan oksigen dan nutrisi yang cukup yang seharusnya dialirkan oleh darah. Akibatnya janin akan mengalami hambatan pertumbuhan. Apabila preeklampsia tidak ditangani maka akan berpengaruh pada kesehatan ibu dan bayi bahkan dapat menimbulkan kematian. Untuk mendeteksi kondisi dan kesehatan janin ibu perlu melakukan pemantauan gerakan janin (6). Gerakan janin adalah gerakan yang spontan yang dilakukan oleh janin dalam kandungan. Gerakan janin yang menurun dapat menimbulkan risiko komplikasi seperti hambatan pertumbuhan janin dan kelahiran mati. Jika janin diam tidak ada merespon sama sekali rangsangan fisik dan suara diberikan, ibu harus waspada, karena bisa jadi terjadi hipoksia (kekurangan oksigen) akibat janin terlilit tali pusat (7).

Pemantauan gerakan janin adalah metode yang sederhana, murah dan berteknologi rendah. Metode yang digunakan yaitu menghitung gerakan bayi setiap hari. Jumlah gerakan bayi normal sekitar tiga hingga lima kali dalam satu jam, jika hasilnya tidak memuaskan maka harus diperiksa dengan USG (8). Persepsi ibu tentang berkurangnya gerakan janin adalah penanda paling penting dari penurunan aktivitas janin. Ibu dapat mengontrol gerakan janin secara hati-hati dan melaporkan jika terjadi penurunan pergerakan janin kepada dokter atau penyedia layanan kesehatan. Sehingga metode ini dapat mencegah morbiditas dan mortalitas perinatal (7). Meningkatkan kemampuan ibu untuk mengenali tanda-tanda peringatan, agar ibu tepat waktu dalam mencari pertolongan jika terjadi kelainan dari tanda gerakan janin.

Berdasarkan hasil studi pendahuluan yang dilakukan di RSUD Arifin Achmad Provinsi Riau, dari data rekam medik Ruang Teratai 1 Rawat Inap, angka kejadian preeklampsia pada tahun 2018 terdapat 107 kasus. Rincian kasus preeklampsia pada ibu usia 15-24 tahun sebanyak 17 kasus, pada ibu usia 22-24 tahun sebanyak 89 kasus, dan ibu usia 45 tahun sebanyak 1 kasus. Hasil wawancara terhadap 6 pasien ibu hamil dengan preeklampsia, diperoleh informasi 2 pasien ibu mengetahui tentang preeklampsia. Pasien tersebut selalu memeriksakan kehamilannya ke tenaga kesehatan dan selalu memeriksakan kehamilan dengan teratur, tetapi tetap mengalami preeklampsia. Sedangkan 4 pasien preeklampsia lainnya tidak mengetahui tentang preekalampsia, tidak memeriksakan kehamilan secara teratur ke tenaga kesehatan, dan memiliki persepsi jika ibu mendapatkan waktu istirahat, itu sudah cukup untuk menjamin kesehatan janinnya. Ibu-ibu tersebut hanya melakukan pemantauan gerakan janin sekali saja dalam sehari, bahkan ada yang tidak melakukan pemantauan gerakan janin. Hal yang penting dilakukan oleh ibu hamil tidak hanya mengetahui hal yang terkait dengan kondisi ibu saja tetapi juga hal-hal terkait kondisi janinnya.

Pemantauan gerakan janin merupakan hal yang sangat penting, namun tidak banyak ibu yang memiliki pengetahuan tentang pemantauan gerakan janin. Hal ini karena masih banyak ibu belum terpapar tentang informasi mengenai pentingnya pemantauan gerakan janin. Kebanyakan ibu 
beranggapan bahwa pemantauan gerakan janin hanya dapat dilakukan oleh tenaga kesehatan dengan menggunakan alat-alat medis (9). Penelitian ini bertujuan untuk mengetahui lebih jauh mengenai tingkat pengetahuan ibu hamil tentang pemantauan gerakan janin. Hasil penelitian ini diharapkan dapat memberikan kontribusi pada upaya penurunan angka kematian bayi dan ibu.

\section{Metode}

Jenis penelitian yang digunakan adalah penelitian kuantitatif dengan desain penelitian deskriptif sederhana. Populasi pada penelitian ini yaitu seluruh ibu hamil dengan preeklampsia yang berada di Ruang Rawat Inap Teratai 1 dan Poli Kebidanan Rawat Jalan di RSUD Arifin Achmad Provinsi Riau berjumlah 85 orang selama bulan Juli 2019. peneliti menetapkan batas waktu penelitian selama \pm 1 bulan. Kriteria sample yaitu berada di lokasi pada selang waktu penelitian dan bersedia di wawancarai, sehingga dalam kurun waktu penelitian diperoleh sejumlah 46 responden. Teknik sampling yaitu accidental sampling yaitu teknik sampling berdasarkan incidental/kebetulan bertemu dengan peneliti di lokasi penelitian selama batasan waktu tanggal 16 Juli sampai dengan tanggal 5 Agustus 2019. Instrumen pengumpulan data menggunakan kuesioner. Kuesioner yang digunakan adalah kuesioner dalam bentuk pernyataan tertutup dimana sudah terdapat jawaban, sehingga responden tinggal memilih jawaban. Kuesioner yang digunakan untuk menggali informasi terkait pengetahuan ibu tentang pemantauan gerakan janin pada ibu hamil dengan preeklampsia. Sebelum pengambilan data, peneliti meminta persetujuan dan kesediaan responden untuk mengisi kuesioner (10).

Uji validitas dilakukan satu kali di RSUD Petala Bumi terhadap 30 responden yang berbeda. Uji validitas dilakukan pada 27 item pernyataan. Hasil uji validitas untuk pernyataan tingkat pengetahuan tentang gerakan janin terdapat 24 pernyataan dinyatakan valid dengan nilai tertinggi ${ }_{r}(0,943) \geq r_{r}$ table $(0,361)$. Pernyataan yang tidak valid dibuang tanpa menambahkan pernyataan baru karena pernyataan yang valid sudah mewakili pertanyaan yang dibutuhkan oleh peneliti (11). Penelitian ini menggunakan uji cronbach"s alpha dengan nilai konstanta 0,60. Hasil uji reliabilitas didapatkan bahwa nilai cronbach"s alpha tingkat pengetahuan tentang gerakan janin sebesar 0,983 yang artinya dikatakan reliable karena lebih besar dari $\mathrm{r}_{\mathrm{r}}$ table $(0,60)$. Analisis data dilakukan secara univariat yaitu dengan menghitung skor jawaban. Masing-masing pertanyaan diberikan skor satu jika menjawab dengan benar, dan skor nol jika jawabannya salah. Skor yang benar kemudian ditotal dan dikalikan 100\%. Nilai skor yang telah dipresentsekan dikategorikan menjadi tingkat pengetahuan tinggi, sedang, rendah. Pengetahuan tinggi jika skor yang didapat 5 responden (10,9\%), pengetahuan sedang jika skor yang didapatkan oleh 4 responden $(8,7 \%)$, rendah jika skor yang didapat oleh 37 responden $(80,4 \%)$.

\section{Hasil dan Pembahasan}

Dari hasil penelitian didapat digambarkan karakteristik 46 responden berdasarkan umur terbanyak berada pada kelompok usia >=35 tahun (73,9\%). Menurut data 16\% Ibu yang hamil pada usia kurang dari 20 tahun atau lebih dari 35 tahun memiliki risiko komplikasi preeclampsia. Sehingga disarankan khususnya ibu hamil dengan umur beresiko untuk melakukan pemeriksaan kehamilansecara teratur, istirahat yang cukup untuk mencegah terjadinya preeklampsia (12). Risiko yang sama juga terjadi pada ibu yang pada kehamilan pertamanya pernah mengalami preeklampsia maka pada kehamilan berikutnya juga akan mengalami hal yang sama, kehamilan kembar, jeda 10 tahun dari kehamilan sebelumnya dan hamil yang disertai obesitas (13).

Lebih dari separuh responden berpendidikan Menengah yaitu 58,7\%. Pendidikan adalah suatu proses untuk memperoleh kemampuan untuk kebiasaan berpikir sebagai suatu kegiatan dalam memecahkan berbagai masalah. Pendidikan sangat mempengaruhi pengetahuan ibu dalam pemantauan gerakan janin, makin tinggi pendidikan seseorang akan semakin luas juga pengetahuan yang dimiliki seseorang tersebut. Pendidikan diperlukan untuk mendapatkan informasi misalnya hal-hal yang menunjang kesehatan sehingga dapat meningkatkan kualitas 
hidupnya, seperti informasi seputar kesehatan khususnya dalam cara pemantauan gerakan janin pada ibu hamil (14). Pendidikan akan mempengaruhi proses belajar, serta usaha untuk meningkatkan kepribadian maupun kedewasaan. Semakin tinggi pendidikan yang didapat seseorang, maka kedewasaannya semakin matang, mereka dengan mudah untuk menerima dan memahami suatu informasi yang positif. Pengetahuan sangat erat hubungannya dengan pendidikan, seorang pendidikan yang tinggi, maka orang tersebut akan semakin luas pengetahuannya, namun tidak menutup kemungkinan pendidikan yang rendah tidak berarti memiliki pengetahuan yang rendah pula. Pendidikan yang tinggi sangat membantu ibu hamil mengetahui apa yang terjadi pada dirinya dan janinnya sehingga kehamilan akan lebih aman (15).

Pekerjaan responden terbanyak adalah sebagai ibu rumah tangga (60,9\%). Ibu Rumah Tangga memiliki banyak waktu untuk memperhatikan janin yang dikandungnya, termasuk melakukan pemantauan gerakan janin. Menurut penelitian Budiarto, Putri, dan camelia (16), bekerja merupakan aktivitas pokok yang dilakukan dengan rutin untuk menunjang perekonomian keluarga dan memiliki manfaat positif terhadap jaminan pembiayaan kesehatan sehingga menjadi salah satu indikator kesehatan. Akan tetapi dalam penelitian ini pekerjaan terkait dengan waktu luang yang dapat digunakan ibu untuk melakukan aktifitas pemantauan gerakan janin. Responden yang bekerja sebagai Ibu Rumah Tangga bisa memantau gerakan janin secara rutin tanpa harus memikirkan pekerjaan yang lain selain pekerjaan rumah, dan bisa meluangkan waktu untuk minimal satu jam untuk memantau gerakan janin. Untuk lengkapnya dapat dilihat pada tabel 1:

Tabel 1. Karakteristik Responden Berdasarkan Umur, Pendidikan, dan Pekerjaan

\begin{tabular}{llll}
\hline \multicolumn{1}{c}{ Karakteristik Responden } & & $\boldsymbol{F}$ & $\boldsymbol{\%}$ \\
\hline Usia $<=35$ tahun & 34 & 73,9 \\
Usia $>36$ tahun & 12 & 26,1 \\
\hline Rendah & 5 & 10,9 \\
Menengah & 27 & 58,7 \\
Tinggi & 14 & 13,4 \\
\hline PNS & 5 & 10,9 \\
Wiraswasta & 3 & 6,5 \\
Swasta & 10 & 21,7 \\
IRT & 28 & 60,9 \\
\hline Jumlah & 46 & 100 \\
\hline
\end{tabular}

Kehamilan ditandai dengan adanya perubahan metabolik dan hemodinamik mulai pada awal periode kehamilan. Perubahan hemodinamik yang utama meliputi peningkatan curah jantung selama trimester pertama, retensi natrium dan air yang mengarah ke ekspansi volume plasma dengan puncaknya sekitar minggu ke 30, dan berkurangnya resistensi vaskuler sistemik dan tekanan darah sistemik. Preeklampsia adalah gangguan kesehatan yang serius pada janin seperti gagal jantung, eklampsia, solusio plasenta, perdarahan, kelainan pembekuan darah, berkurangnya aliran darah menuju plasenta, sindrom HELLP (hemolisis, elevated liver enzymes, and low platelet count), ablasio retina, lepasnya plasenta, diabetes dan kematian, sehingga preeklampsia harus ditangani dengan benar agar tidak menimbulkan kejadian yang membahayakan pada janin. Penting bagi ibu preeklampsia mengetahui gerakan janin karena ketika terjadi peningkatan tekanan darah, maka akan terjadi vasopresin dan menurunnya aliran darah. Komplikasi janin berhubungan secara langsung dengan keparahan penyakit, ketika terjadi vasokontriksi pembuluh darah otomatis aliran darah ibu ke janin akan berkurang dan menyebabkan bayi akan kekurangan oksigen, nutrisi sehingga pertumbuhan janin terhambat. Lepasnya plasenta bisa terjadi perdarahan dan dapat mengancam keselamatan pada janin. Gangguan perfusi plasenta menimbulkan degenerasi plasenta lebih dini dan kemungkinan IUGR (Intrauterine Growth Restriction) pada janin. Preeklampsia akan berkontribusi secara signifikan terhadap hambatan 
pertumbuhan janin dan insiden abrupsio plasenta. Gangguan perfusi plasenta akan menyebabkan degenerasi dini pada plasenta (6).

Hasil penelitian ini menemukan sebanyak $80,4 \%$ ibu preeklampsia memiliki tingkat pengetahuan ibu hamil dengan preeclampsia masih kurang tentang pemantauan gerakan janin. Menurut Notoatmodjo (12) pengetahuan merupakan unsur yang sangat penting dalam terbentuknya suatu tindakan perilaku yang menguntungkan suatu kegiatan. Temuan penelitian ini sejalan dengan hasil penelitian Prabavathy dan Dash (17), yang juga menemukan separoh $(50 \%)$ ibu bersalin memiliki pengetahuan yang kurang tentang menghitung gerakan janin dan $13,3 \%$ ) ibu dengan kehamilan normal memiliki pengetahuan yang baik tentang menghitung gerakan janin. Prabavanthy juga menemukan ada hubungan yang signifikan antara variabel tingkat pengetahuan dengan variabel usia kehamilan. Tingkat pengetahuan Ibu seperti ditunjukkan pada tabel 2 .

Tabel 2. Tingkat Pengetahuan Ibu Tentang Pemantauan Gerakan Janin

\begin{tabular}{|l|l|l|}
\hline Pengetahuan tentang Pemantauan Gerakan Janin & \multicolumn{1}{|c|}{$\boldsymbol{F}$} & \multicolumn{1}{|c|}{$\%$} \\
\hline Baik & 5 & 10,9 \\
Cukup & 4 & 8,7 \\
Kurang & 37 & 80,4 \\
\hline Jumlah & 46 & 100 \\
\hline
\end{tabular}

Analisis kuesioner dilakukan dengan melihat persentase skor jawaban responden yang benar dan jawaban yang salah. Berdasarkan data bahwa sebagian besar responden yaitu 40 orang $(87,7 \%)$ menjawab gerakan janin tidak dapat menggambarkan kondisi kesehatan pada janin. Padahal kondisi gerakan janin menggambarkan kesehatan janin. Menurut penelitian Hatini gerakan janin merupakan gerakan spontan yang dilakukan oleh janin dalam kandungan ibu. Pergerakan janin yang berubah sepanjang kehamilan menunjukkan perkembangan janin. Menurut Lowdermilk, Perry dan Cashion (6) pemantauan gerakan janin pada ibu dengan preeklampsia juga dapat mengetahui kondisi janin dan tidak hanya untuk kondisi ibu. Ibu yang lebih aktif merasakan gerakan janin, dapat pula meningkatkan ikatan kasih sayang antara ibu dan janin. Menurut penelitian Delaram dan Jafarzadeh (7), manfaat pemantauan gerakan janin adalah menilai kesehatan janin. Perhitungan gerakan janin setiap hari tujuannya yaitu dapat meningkatkan kemampuan ibu untuk mengenali tanda-tanda peringatan lebih cepat dan kondisi janin dalam bahaya. Memantau gerakan janin normalnya paling sedikit sepuluh gerakan per hari. Gerakan janin yang menurun dapat menimbulkan resiko komplikasi seperti hambatan pertumbuhan janin dan kelahiran mati. Ketika ibu selalu memantau gerakan janin dan melaporkan penurunan waktu pergerakan janin kepada dokter atau penyedia tenaga kesehatan, supaya tujuan untuk mencegah morbiditas dan mortalitas perinatal. Berdasarkan hasil penelitian Mc .Cowman,. et al (2019), mengatakan bahwa 99,9\% ibu hamil mengatakan penting bagi mereka untuk merasakan bayi bergerak setiap hari. Banyak ibu hamil yang menginginkan dan menerima informasi tentang pergerakan janin, namun antara $25-60 \%$ ibu hamil tidak menerima informasi tentang gerakan janin. Meskipun kurang efektivitas dalam perhitungan gerakan janin, ibu hamil tersebut terus diberi tahu tentang gerakan janin yang normal. Beberapa penyediaan perawatan bersalin juga mengakui bahwa pentingnya ibu tentang gerakan janin (18).

Responden mengakui belum terpapar informasi mengenai pentingnya pemantauan gerakan janin dan beranggapan bahwa memantau gerakan janin harus dilakukan oleh tenaga kesehatan dan menggunakan alat-alat medis. Menurut Thistle dan Bryant (2018) penyedia layanan kesehatan perlu menginstruksikan ibu hamil untuk memantau pergerakan janin, terutama pada trimester ketiga. Ibu hamil perlu diberi kesadaran tentang penting memantau gerakan janin, apakah janin bergerak kurang dari normal pada hari tertentu atau hampir sama dengan hari-hari yang lain-lainnya (8). Pengetahuan merupakan salah satu faktor yang penting dalam kesehatan ibu dan bayi karena pengetahuan yang baik, maka ibu akan menerima segala informasi dari luar. 
Terutama tentang cara penatalaksanaan pada preeklampsia dan cara pemantauan gerakan janin. Menurut Hartini (2018) gerakan janin merupakan gerakan spontan yang dilakukan oleh janin dalam kandungan ibu. Ibu dapat melakukan penghitungan gerakan janin (Fetal Movement Count) sejak kehamilan 28 minggu setelah sistem saraf pusat dan autonomi berfungsi dengan optimal (19). Sebagian besar responden (95,7\%) menjawab harus menghitung gerakan janin setiap hari, dengan cara pada saat bangun pagi hari. Kemudian ibu mencatat sepuluh kali gerakan selama 2-3 jam. Jika gerakan janin kurang dari sepuluh gerakan selama 2-3 jam, ibu harus pergi ke pelayanan kesehatan. Ada dua cara dalam melakukan pemantauan gerakan janin yaitu cara Cardiff, yaitu pemantauan dilakukan mulai dari jam 9 pagi, tidur miring ke kiri atau duduk, menghitung berapa waktu yang diperlukan untuk mencapai sepuluh gerakan janin. Sedangkan cara Sadovsky adalah pemantauan dilakukan pasien tidur miring kekiri, kemudian hitung gerakan janin. Harus dapat dicapai empat gerakan janin dalam satu jam, bila belum tercapai waktunya ditambahkan satu jam lagi. Waktu akan mulai perhitungan gerak janin, dianjurkan ibu hamil makan terlebih dahulu, mengosongkan kandung kemih, dan tidur miring ke kiri agar sirkulasi uteroplasenta tidak terganggu (19).

Sebagian besar responden $(84,4 \%)$ menjawab pemantauan gerakan janin tidak bisa dilakukan di rumah. Padahal menurut teori tentang penatalaksanaan keperawatan, memantau gerakan janin bisa dilakukan ibu di rumah dengan aman. Salah satu pemantauan gerakan janin adalah dengan cara meletakkan lebih dari 10 uang logam dalam mangkok, letakkan mangkok diatas meja. Setiap kali janin bergerak, masukkan logam ke dalam mangkuk, jika logam tidak kembali lagi seluruhnya kedalam mangkuk dalam waktu 12 jam, segera hubungi atau konsultasi ke pelayanan kesehatan. Selain itu bisa juga dengan cara menghitung gerakan janin di pagi hari setelah makan (20). Menurut Lowdermilk, Perry dan Cashion, (6) penatalaksanaan keperawatan ibu hamil dengan preeklampsia adalah dengan melakukan pemeriksaan ibu dan janin: memantau gerakan janin, NST atau profil biofisik sekali atau dua kali seminggu, dan pemeriksaan volume cairan amnion dan berat janin dengan USG pada saat didiagnosis hipertensi gestasional atau PER tergantung hasil pemeriksaan. Menurut Delaram dan Jafarzadeh (7), ketika ibu selalu memeriksakan kehamilan ke tenaga kesehatan dengan tepat waktu, maka ia dapat menilai kesehatan janin. Keterbatasan dalam penelitian adalah dikarenakan kondisi dan keluhan rasa sakit yang dialami oleh pasien mengakibatkan proses pengisian kuesioner terhambat dan sering terjadi pemutusan komunikasi oleh responden, sehingga data yang terkumpul belum tentu menggambarkan apa yang benarbenar diketahui oleh responden. Saran untuk penelitian selanjutnya bisa melakukan penelitian dengan menggunakan metode dan pendekatan yang berbeda dan melihat hubungan tingkat pengetahuan ibu hamil tentang pemantauan gerakan janin dengan kejadian preeklampsia. Hasil persentase skor jawaban responden yang benar dan jawaban yang salah seperti terlihat pada tabel 3.

Tabel 3. Pengetahuan Ibu dengan Preeklampsia tentang Pemantauan Gerakan Janin

\begin{tabular}{|c|c|c|c|c|}
\hline \multirow[t]{2}{*}{ Pernyataan } & \multicolumn{4}{|c|}{ Jawaban } \\
\hline & Benar & $\%$ & Salah & $(\%)$ \\
\hline $\begin{array}{lccc}\text { Gerakan janin } & \text { menandakan } & \text { janin } & \text { mengalami } \\
\text { pertumbuhan dan perkembangan } & & \end{array}$ & 38 & 82,6 & 8 & 17,4 \\
\hline Gerakan janin menurun, tanda bahaya pada janin & 24 & 52,2 & 22 & 47,8 \\
\hline $\begin{array}{l}\text { Ketidakstabilan tekanan darah pada ibu hamil dapat } \\
\text { mempengaruhi kesehatan janin }\end{array}$ & 16 & 34,8 & 30 & 65,2 \\
\hline $\begin{array}{l}\text { Ppeningkatan tekanan darah selama kehamilan } \\
\text { menyebabkan aliran darah ke janin menurun }\end{array}$ & 20 & 43.5 & 26 & 56,5 \\
\hline Gerakan janin meningkat; tekanan darah meningkat & 14 & 30,4 & 32 & 69,6 \\
\hline $\begin{array}{l}\text { Pemantauan gerakan janin hanya diperiksa dengan } \\
\text { menggunakan alat kesehatan }\end{array}$ & 17 & 37 & 29 & 63,0 \\
\hline Gerakan janin tidak menggambarkan kesehatan janin & 6 & 13 & 40 & 87,0 \\
\hline
\end{tabular}




\begin{tabular}{|c|c|c|c|c|}
\hline $\begin{array}{l}\text { Kurangnya pemantauan gerakan janin tidak akan } \\
\text { menurunkan resiko kematian janin }\end{array}$ & 15 & 32,6 & 31 & 67,4 \\
\hline $\begin{array}{l}\text { Jika gerakan janin berkurang, ibu hanya perlu istirahat } \\
\text { tanpa ke pelayanan kesehatan (Rumah Sakit dan } \\
\text { Puskesmas) }\end{array}$ & 9 & 19,6 & 37 & 80,4 \\
\hline $\begin{array}{l}\text { Ibu harus menghitung gerakan janin paling sedikit } 3 \text { kali } \\
\text { dalam } 1 \text { jam sehari }\end{array}$ & 8 & 17,4 & 38 & 82,6 \\
\hline $\begin{array}{l}\text { Cara menilai kesehatan janin adalah dengan mencatat } \\
\text { jumlah gerakan janin selama } 1 \text { jam setelah makan }\end{array}$ & 12 & 26,1 & 34 & 73,9 \\
\hline $\begin{array}{l}\text { Apabila bayi tidak bergerak, ibu bisa mengajak bayi bicara } \\
\text { dan mengelus-mengelus perut }\end{array}$ & 11 & 23,9 & 35 & 76,1 \\
\hline $\begin{array}{l}\text { Dengan waktu } 12 \text { jam, gerakan janin setidaknya kurang } \\
\text { dari } 10 \text { gerakan }\end{array}$ & 9 & 19,6 & 37 & 80,4 \\
\hline Pemantauan gerakan janin tidak bisa dilakukan di rumah & 7 & 15,2 & 39 & 84,4 \\
\hline Gerakan janin kurang pertanda kondisi bayi tidak baik & 13 & 28,3 & 33 & 71,7 \\
\hline $\begin{array}{l}\text { Uang logam dan mangkok bisa membantu ibu untuk } \\
\text { menghitung gerakan janin }\end{array}$ & 2 & 4,3 & 44 & 95,7 \\
\hline $\begin{array}{l}\text { Manfaat pemantauan gerakan janin adalah dapat } \\
\text { meningkatkan ikatan batin ibu dan janin }\end{array}$ & 15 & 32,6 & 31 & 67,4 \\
\hline $\begin{array}{l}\text { Jika janin diam tidak ada respon sama sekali, ibu harus } \\
\text { lebih memperhatikan kondisi janin }\end{array}$ & 13 & 28,3 & 33 & 71,7 \\
\hline Terlilit tali pusat menyebab gerakan janin kurang & 16 & 34,8 & 30 & 65,2 \\
\hline Turunnya gerakan janin, beresiko pada kelahiran mati & 14 & 30,4 & 32 & 69,6 \\
\hline $\begin{array}{l}\text { Gerakan janin sudah bisa dirasakan ibu saat memasuki } \\
\text { usia kehamilan } 16-20 \text { minggu ( } 5 \text { bulan) }\end{array}$ & 16 & 34,8 & 30 & 65,2 \\
\hline $\begin{array}{l}\text { Saat ibu memantau gerakan janin harus dilakukan dengan } \\
\text { posisi duduk dan tidur miring }\end{array}$ & 12 & 26,1 & 34 & 73,9 \\
\hline $\begin{array}{l}\text { Banyak melakukan aktivitas dan banyak bergerak akan } \\
\text { membuat janin menjadi tenang bahkan tertidur }\end{array}$ & 13 & 28,3 & 33 & 71,7 \\
\hline $\begin{array}{l}\text { Ibu harus menghitung gerakan janin setiap hari, dengan } \\
\text { cara pada saat bangun pagi hari, memantau gerakan janin } \\
\text { selama } 2-3 \text { jam, jika kurang dari } 10 \text { gerakan, maka ibu } \\
\text { harus pergi ke pelayanan kesehatan }\end{array}$ & 44 & 95,7 & 2 & 4,3 \\
\hline
\end{tabular}

\section{Kesimpulan}

Tingkat pengetahuan ibu dengan preeklampsia tentang pemantauan gerakan janin sebagian besar $(80,4 \%)$ masih kurang. Banyak ibu yang menjawab salah pernyataan yang diberikan pada kuesioner. Misalnya pernyataan tentang manfaat dan pentingnya pemantauan gerakan janin, cara melakukan pemantauan gerakan janin. Masih rendahnya pengetahuan ibu preeclampsia tentang pemantauan gerakan janin menunjukkan bahwa perjuangan untuk mencapai tergat penurunan kematian bayi dan kematian ibu masih membutuhkan perjuangan yang panjang. Keberhasilan program dapat dicapai jika ada partisipasi aktif ibu hamil dalam melakukan kegiatan pencegahan melalui pemantauan gerakan janin. Peningkatan pengetahuan ibu tentang pemantauan gerakan janin penting menjadi perhatian tenaga kesehatan untuk bisa menurunkan angka kematian ibu dan janin.

\section{Ucapan Terimakasih}

Penulis mengucapkan terima kasih kepada Ns. Dian Roza Adila, M. Kep, Ns. Riau Roslita, M. Kep, Sp. Kep. An selaku Dosen pembimbing, dan berbagai pihak lain yang telah membantu dengan memberikan masukan sebagai penulis selama menyelesaikan penelitian. 


\section{Konflik Kepentingan}

Tidak ada konflik kepentingan.

\section{Referensi}

1. UNICEF. Laporan PBB - untuk pertama kalinya, angka perempuan dan anak yang bertahan hidup capai tingkat tertinggi.

2. Kemenppa RI. Profil Kesehatan Anak Indonesia Tahun 2018. 2018. 58 p.

3. Kementerian Pemberdayaan Perempuan dan Perlindungan Anak dan Badan Pusat Statistik. Profil Anak Indonesia Tahun 2019. Kementeri Pemerdayaan Peremp dan Perlindngan Anak. 2019;378.

4. Gongora MC, Wenger NK. Cardiovascular complications of pregnancy. Int J Mol Sci. 2015;16(10):23905-28.

5. Tessier DR, Yockell-Lelièvre J, Gruslin A. Uterine spiral artery remodeling: the role of uterine natural killer cells and extravillous trophoblasts in normal and high-risk human pregnancies. Am J Reprod Immunol. 2015;74(1):1-11.

6. Detiana P. Hamil Aman dan Nyaman di Atas 30 Tahun. Media Pressindo; 2010.

7. Lowdermik DL, Perry SE, Cashion K. Keperawatan Maternitas Edisi 8 Buku 1. Singapore: Elsevier Pte Ltd; 2013.

8. Delaram M, Jafarzadeh L. The effects of fetal movement counting on pregnancy outcomes. J Clin diagnostic Res JCDR. 2016;10(2):SC22.

9. Enkhmaa D, Wall D, Mehta PK, Stuart JJ, Rich-Edwards JW, Merz CNB, et al. Preeclampsia and vascular function: a window to future cardiovascular disease risk. J Women's Heal. 2016;25(3):284-91.

10. Flenady V, Ellwood D, Bradford B, Coory M, Middleton P, Gardener G, et al. Beyond the headlines: Fetal movement awareness is an important stillbirth prevention strategy. Women and Birth. 2019;32(1):1-2.

11. Nursalam D. Manajemen Keperawatan" Aplikasi dalam Praktik Keperawatan Profesional. Salemba Medika; 2014.

12. Riyanto A. Aplikasi metodologi: penelitian kesehatan. Nuha Medika; 2011.

13. Nursal DGA, Tamela P, Fitrayeni F. Faktor Risiko Kejadian Preeklampsia pada Ibu Hamil di Rsup Dr. M. Djamil Padang Tahun 2014. J Kesehat Masy Andalas. 2017;10(1):38-44.

14. Sutrimah S, Mifbakhudin M, Wahyuni D. Faktor-faktor yang Berhubungan dengan Kejadian Preeklampsia pada Ibu Hamil di Rumah Sakit Roemani Muhammadiyah Semarang. J Kebidanan. 2015;4(1):1-10.

15. Wawan A, Dewi M. Teori dan Pengkukuran Pengetahuan, Sikap Dan Perilaku Manusia: Yogyakarta. Nuha Medika. 2011.

16. Notoatmodjo S. Metodologi penelitian kesehatan. PT. Rineka Cipta; 2012.

17. Budiarti V, Putri R, Amelia CR. Hubungan karakteristik ibu dan dukungan suami dengan tingkat pengetahuan ibu hamil tentang tanda bahaya kehamilan. J Issues Midwifery. 2018;2(1):1-18.

18. Prabavathy M, Dash MB. Assess the knowledge of fetal movements count among antenatal mothers in RGGWCH, Puducherry. Innov J Nurs Healthc. 2017;2(4):2-4.

19. Bradford BF, Cronin RS, McKinlay CJD, Thompson JMD, Mitchell EA, Stone PR, et al. A diurnal fetal movement pattern: Findings from a cross-sectional study of maternally 
perceived fetal movements in the third trimester of pregnancy. PLoS One. 2019;14(6):e0217583.

20. Hatini EE. Pendampingan Pengkajian Kesejahteraan Janin Pada Ibu Hamil Trimester Iii di Kelurahan Kereng Bangkirai. Pros Pengabmas. 2018;1(1):152-7. 